\title{
EXAMPLES OF UNUSUAL CONSTRUCTION SCAFFOLDINGS USED FOR RENOVATION WORKS OF HISTORIC BUILDINGS
}

\author{
Aleksander ROBAK ${ }^{1}$, Michał PIEŃKO, Ewa BŁAZIK-BOROWA \\ Lublin University of Technology, \\ Faculty of Civil Engineering and Architecture, Lublin, Poland
}

\begin{abstract}
A few examples of scaffoldings designed, built and used in recent years in Poland have been presented here in this paper. There have been described facilities of various forms, which are surrounded by scaffoldings. This makes the design and assembly processes demand large labour input. The main focus has been set to the problems in the operation of scaffoldings used during the renovation of historic monuments. The scaffoldings used at such buildings are usually of complex and alternating geometry. In extreme cases, it is impossible to anchor the scaffolding due to the mechanical sensitivity of building facades. Other problem often affecting the operation of scaffoldings near such buildings is large inclination of roof surfaces, at which the scaffoldings are based on.
\end{abstract}

Keywords: scaffolding, static analysis, static scheme

\section{INTRODUCTION}

The most common scaffolding task at the construction site is to create a work zone in tight spaces both outside and inside buildings. However, they do not often perform additional functions such as.: covering, protection against weather, traffic routes, protection of work areas, supporting structures. Construction and renovation at historic buildings form an additional challenge

\footnotetext{
${ }^{1}$ Corresponding author: Lublin University of Technology, Faculty of Civil Engineering and Architecture, Department of Structural Mechanics Nadbystrzycka str. 36, 20-618 Lublin, Poland, e-mail: a.robak@pollub.pl, tel.+48815384433, e-mail: m.pienko@pollub.pl tel.+48815384437, e-mail: e.blazik@pollub.pl, tel.+48815384433
} 
for the use of scaffolding due to the complexity often unique shape of the building. Therefore at historic buildings generally one does not apply common solutions, advertised in catalogues of manufacturers. This implies adoption of each individual solutions and hence checking the structure by means of static calculations. Scaffoldings-should provide security for work, but it cannot also interfere with normal functioning of the renovated building. Scaffolding failures are mainly due to faulty estimation of mechanical resistance and stability, as well as the false anchoring and foundation of scaffolding. It should be added that in the case of scaffolding with complex geometric configuration it is required to carry out static-strength calculations. A detailed description of the individual construction project requirements of scaffoldings was described in a work [3]. Construction scaffolding, despite the not too large dimensions of the cross sections in typical situations, i. e. when most of the scaffold elements are compressed or stretched, carries a significant burden. However, in the case where there is a bending of elements, carrying capacity of the scaffold decreases drastically. Therefore, such constructions must be installed in such a way as to avoid elements bending and if there is elements bending, one should determine the maximum load by the means of a static analysis.

\section{EXAMPLES OF PROJECTS}

The following examples illustrate the variety of problems encountered in the design of scaffolding. Presented structures are examples of assembled structures and used in recent years.

\subsection{Scaffolding around the dome of the Church of the Holy Apostles Peter and Paul in Kraków}

One example of unique scaffolding is a construction that has been set for the Church of Saints Peter and Paul in Kraków. Renovation work carried out in 2014 on this object relate to peak tower of building at the height of approx. $57 \mathrm{~m}$ (Fig. 1c). In this structure there is no restriction to anchoring the scaffold and the possible support of scaffolding structure on the roof (Fig. 1b). Here the biggest problem turned out to be a very large angle of roof spread slope and the round shape of the structure. In addition to the scaffold, located right around the renovated tower, one made structure composed of several platforms and vertical walls, providing communication from ground level up to the cross located on the top of the tower. The first longest circulation path, shown in Fig 1a, was initially realized with a scaffold of dimensions $2.5 \mathrm{~m} \times 0,73 \mathrm{~m}$ and applying catwalks with transition flaps and aluminium ladders. Eventually this path was modified adding a second module with a width of $0,73 \mathrm{~m}$ allowing replacing 
temporary catwalks with stair courses significantly improving communication at this point. Above level 9 scaffold was based on church roof with tilt stands. Stands located in this manner, one needs to devote special attention and care in order to supply each of them with a tube fitting anchored to the wall. If this is not possible in the case of long-span roofs, as in the illustrated instance, stands should be combined with the scaffold structure using additional hardenings. One should take care of anchor or fixed hardening to be anchored to stand as low as possible.

a)

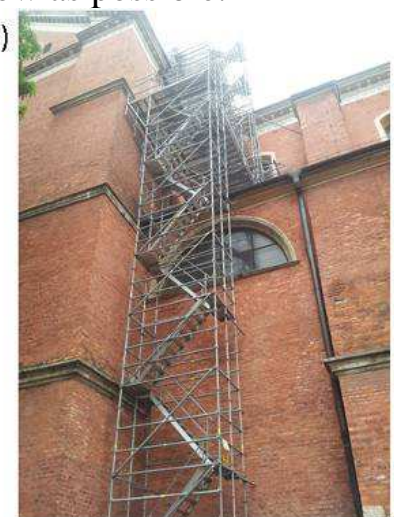

b)

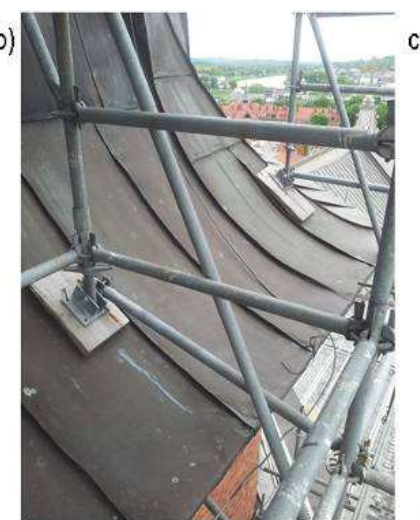

c)

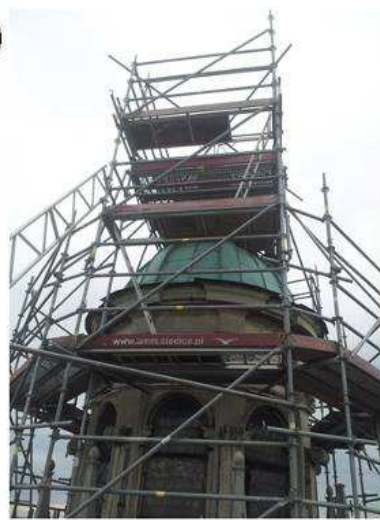

Fig. 1. Scaffolding at the church of Saints Peter and Paul in Kraków: a) circulation path, b) adjusting the tilt stand c) the crowning of the scaffolding

\subsection{Scaffolding on the facades of the Castle in Pieskowa Skała}

Another presented scaffolding is the design used at the castle in Pieskowa Skała in 2014 (Figure 2). Unlike in the previously illustrated example, at the castle in Pieskowa Skała renovations were carried out on external walls of the objects. In this case it was decided to use a framed scaffolding. The benefits of this assumption are the speed and ease of assembly, and above all, such scaffolding does not need to be further solidified in areas perpendicular to the facade. The first difficulty that appeared during the design of the scaffolding was the need to move the scaffolding horizontally up about one module in order to bring structure to the facade. This was achieved using a system supports, pillared with hardenings and the appropriate placement of anchoring fasteners in the area. The main problem was, however, the place of founding scaffolding, because it was very varied. In places the subsoil was flat and there was no obstacle to lean the scaffolding using the bases. Unfortunately, there were also areas with very high tilting starting directly from the walls of the castle. This situation forced the use of scaffolds suspension which was carried out by means of ancones and steel cranes. View of this mounting was shown in Fig. 3b. 
a)

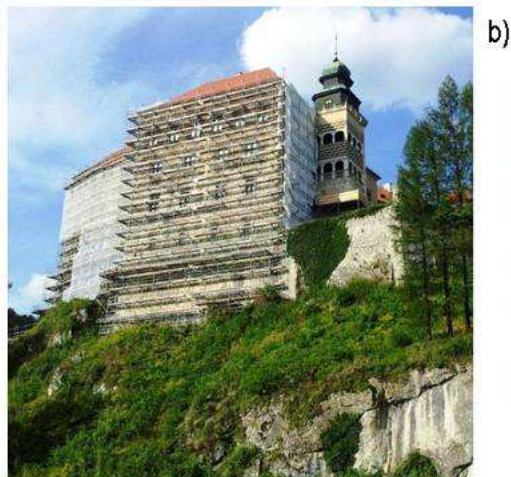

Fig. 2. Scaffolding on the facades of the castle in Pieskowa Skała: a) view of scaffolding, b) adjusting the scaffold on ancones

\subsection{Scaffolding around the Chapel of Karol Scheibler in Lódź}

The chapel was built in 1888 cross plan with dimensions of $25 \times 13.5 \mathrm{~m}$ and is one of the greatest works of cemetery architecture in the world. The property has a slender body, topped with transparent stone tower. The total height of the building is $37 \mathrm{~m}$. In 2010 for the purpose of restoration works of the highest tower of the chapel along with the cross, placed at the top, one designed a scaffold with dimensions in a floor plan of an $11 \mathrm{~m} \times 18 \mathrm{~m}$ and height of $38 \mathrm{~m}$ which stands for 19 levels of scaffolding. Static analysis of scaffolding around the chapel, shown in Figure 3, is described in detail in a work of [1]. The biggest problem at the design stage and the implementation was the lack of a permit for anchoring to the walls of the chapel and the rest on the roof or ledges of the building. The result of these assumptions was to create a selfsupporting structure which does not have any connection with the building, at which it was assembled. Scaffolding was based on subsoil through the wooden groundwork along the side walls of the chapel. The cross section of scaffolding at the ground level is shown in Fig. 4 and it was the same to the ninth scaffolding level of approx. $20 \mathrm{~m}$, where the two side walls of the scaffold were connected by means of ten pairs of steel girders, longitudinally connected with each other.

Such a large number of applied girders were necessary due to the fact that successive levels of scaffolding were based only on the girders that carried forces on the side walls of the scaffold. Above the ninth level of each next level was different from the lower and It resulted from need to adjust the scaffold to the shape of the restored tower. The last highest levels had dimensions of only $2,5 \mathrm{~m} \times 3,5 \mathrm{~m}$. 


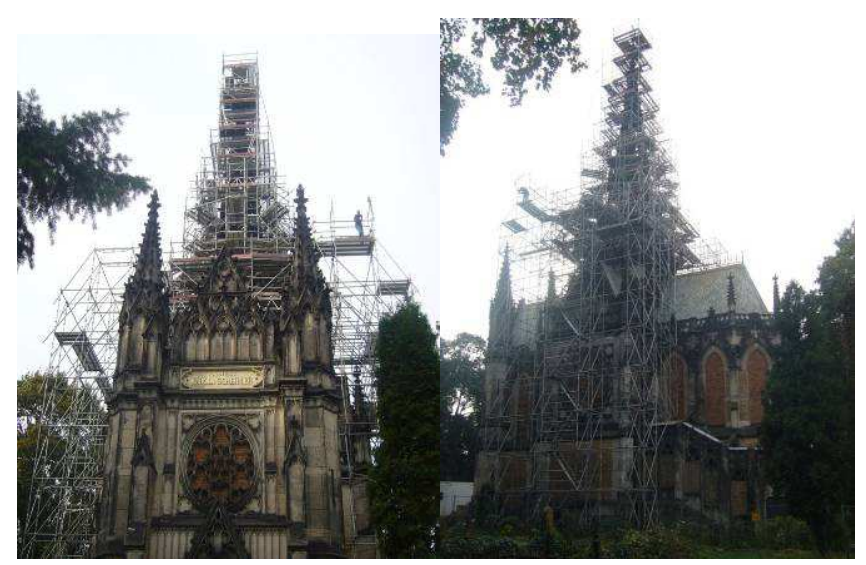

Fig. 3. Scaffolding around the Chapel of Scheibler

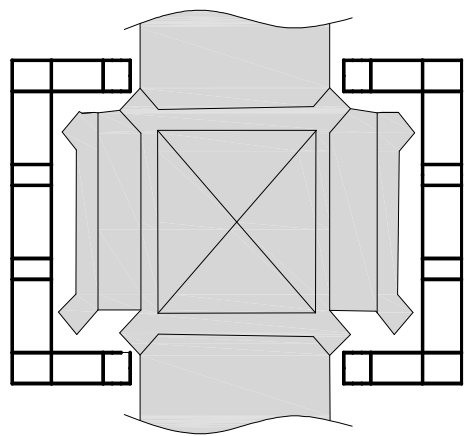

Fig. 4. Cross-section and location of scaffolding at ground level

\section{CONCLUSIONS}

Conceptual scaffolding systems included in the catalogues of manufacturers cannot always be used for complex buildings, with such, one often has to do during renovations of historic buildings. This kind of object requires an individual approach, both on the part of designers and scaffolding fitters. The seemingly minor change in the structure of scaffolding can have a significant impact on the behaviour of the structure. The designer must take into account the possibility of assembling the structure, with the smallest possible contribution of the work and maintaining safety rules. The greatest difficulty in the design are associated with the adoption of a proper static plan with regard to the way the structure is supported, its connections [2], the stability and the use of alternative models [4]. 


\section{REFERENCES}

1. Błazik-Borowa E. Robak A. Pieńko M.: Analiza numeryczna konstrukcji rusztowania modutowego o nietypowym ksztatcie, Zeszyty Naukowe Politechniki Rzeszowskiej, Budownictwo i Inżynieria Srodowiska, zeszyt 58, nr 3/2011/II, str.333-340.

2. Pieńko M., Błazik-Borowa E.: Numerical analysis of load-bearing capacity of modular scaffolding nodes, Engineering Structures vol 48, 2013. p. 1-9.

3. Rawska-Skotniczny A., Rawski H.: $O$ projektowaniu pomocniczych konstrukcji budowlanych $w$ świetle Eurokodów, Inżynieria i Budownictwo nr 2/2010 str 87-91.

4. Robak A. Numeryczne badania wytrzymałości pomostów umieszczanych na rusztowaniach, Budownictwo i Architektura 8/2011 (2011) 67-81.

\section{PRZYKŁADY REALIZACJI NIETYPOWYCH RUSZTOWAŃ BUDOWLANYCH WYKORZYSTYWANYCH DO PRAC RENOWACYJNYCH OBIEKTÓW ZABYTKOWYCH}

\section{Streszczenie}

W przedstawionym opracowaniu przedstawiono kilka przykładów konstrukcji rusztowań budowlanych zaprojektowanych, zmontowanych oraz użytkowanych w ostatnich latach. Opisane zostały obiekty, przy których rusztowania przyjmowały zupełnie różne formy a zagadnienia $\mathrm{z}$ nimi związane przysparzają wielu problemów na etapie projektowania oraz etapie montażu. Główną uwagę zwrócono na zagadnienia związane z użytkowaniem rusztowań podczas prac renowacyjnych obiektów zabytkowych. Rusztowania na takich obiektach charakteryzują się bardzo skomplikowaną i zmienną geometrią. Dodatkowo bardzo często mamy do czynienia $\mathrm{z}$ utrudnieniami takimi, jak brak możliwości zastosowania łączników kotwiących w liczny przewidywanej dla „typowych” schematów konstrukcji a w skrajnych przypadkach ze względu na dużą wrażliwość na oddziaływania mechaniczne, powierzchni, przy których zmontowane jest rusztowanie, braku możliwości kotwienia. Innym często występującym utrudnieniem w tego typu obiektach jest duże pochylenie połaci dachowych, na których oparte jest rusztowanie.

Słowa kluczowe: rusztowania, obliczenia statyczne, schemat statyczny

Editor received the manuscript: 02.02.2015 